\title{
DETERMINANTS OF COMPETITIVENESS IN TEXTILE INDUSTRY OF PAKISTAN
}

\author{
${ }^{1}$ Muhammad Ehsan Javaid, ${ }^{2}$ Muhammad Asim Afridi \\ ${ }^{1}$ Lecturer \\ Lahore Leads University, Lahore \\ Email address: muhammadehsanjavaid@yahoo.com \\ ${ }^{2}$ Assistant Professor \\ COMSATS Institute of Information Technology Abbottabad \\ Email address: asimafridi@ciit.net.pk
}

Keywords: Competitiveness, Efficiency, Exporting, Market Share, Productive Asset.

\begin{abstract}
This study investigated the determinants of competitiveness in textile industry of Pakistan. Both financial (leverage, liquidity, investment, productive asset and firm size) and nonfinancial factors (exporting and market share) were collectively studied from 2002 to 2012 for 84 textile firms. Balanced panel data used for analysis. Hausman test confirmed fixed effect panel data regression model as appropriate research technique. Results proven that leverage, productive asset and firm size had negative significant relationship with competitiveness of firm while market share had positive significant relationship. Extraordinary use of debt financing, inefficient asset management and improper usage of productive asset were the point of main concern for further improvement of firm competitiveness. For capturing large market share firm desired to achieve economies of scale and economies of scope. Exporting and liquidity had positive but insignificant relationship while investment had negative insignificant relationship with competitiveness.
\end{abstract}

\section{INTRODUCTION}

Development in the field of information and technology opened the new world order on the wheels of globalization. This development increased trade both domestically as well as internationally by providing more fluent logical tools and techniques with communication capabilities. Things considered impossible turned into reality today. Increased globalization, cheap but effective communication tools opened the door of international markets for the domestic business firms which helped them to secure more and more profit. First it must be clarified that competitiveness means to do better than rest of all (Murths and Lenway, 1998). It was also defined by Lall (2001) that perform better then all direct competitors and indirect competitors (substitute providers) in each and every aspect to secure more profit that gave competitive edge over others. Lall (2001) made it clear that to avoid from being trap in the net of competitiveness, its recommended for easiness to measure it through profitability of firm. Momaya and Selby (1998) further clarified that competition was not limited to a firm only. It may be a sector as well as country.

One side of the picture showed that as domestic business firms had less capabilities and competitive potentials, now got the access of developed markets. Other side of this picture must be considered for proper evaluation which indicated that firms operated in developed market were attracted toward underdeveloped markets for diversification of risk and to boost customer base. Firms in underdeveloped market faced this threat because of no capability for competing against firms of developed markets. Firms reached the maximum limit of customer base in developed market because of intense competition. Removal of restriction proved more fruitful for international firms. This openness increased the competition in underdeveloped market as well which initiated the need to study competitiveness issue again. 
Economic Survey of Pakistan confirmed that textile business was the most auspicious and mounting in Pakistan and during year 2012 it contributed the 8.5\% of total GDP (Gross Domestic Product) whereas Ministry of Finance in 2012 reported that textile contributed $46 \%$ of total manufacturing done in Pakistan. As this sector was the major and important sector in Pakistan's economy so this study focused to identify factors for domestic textile firms to be competitive. Financial and nonfinancial factors were studied and analyzed. Factor had historically proved significant impact on firm competitiveness were considered in this study to identify which one is the most concerned factor now for competitiveness of domestic textile firms.

\section{LITERATURE REVIEW \\ LEVERAGE}

Whenever the discussion issue was firm competitiveness, the first thing that hit the mind sources of funds to achieve competitive edge. Here a question rose that how sources of funding can be used to get competitive edge.

It was answered in MM Hypothesis. Modigliani and Miller proposed that firm's capital structure and firm's profitability was irrelevant under perfect market conditions like when there were no taxes, no transaction costs and investment opportunities were fixed (Modigliani and Miller, 1958). When such conditions were upheld, then change in capital structure either increase or decrease the firm profitability. It was the use of debt instruments in shaping capital structure that give firm competitive edge over its fellows.

Jensen and Meckling (1976) analyzed and highlighted another aspect that how use of debt increased the firm profitability or competitiveness. Using debt as source of financing, tunneling activities were removed which reduced agency cost and conflicts. Firm's management not involved in tunneling activities gave competitive edge.

Miller (1977) highlighted another aspect by mentioning trade off view. Explanation showed that firm wanted to avail tax shield for that debt was first priority. Higher the debt more tax benefit firm avail. However debt accompany with cost of using debt. A very directional statement presented in the study that debt gave competitive edge to firm till cost associated with debt was less than tax benefits availed from it.

Myers and Majluf (1984) extended this work and highlighted pecking order prospective. While deciding how to finance firm operations. Internal financing considered to be the cheapest source, must be used first. If further financing required then must go for debt financing. If more financing still required by the firm then go equity financing, however cost associated with equity financing was huge.

From the above different viewpoints mysterious character of debt was cleared. Like it increased as well as decreased competitiveness of firm depending upon usability. Similar results were also obtained different researches mentioned below and their explanations were covering in above defined approaches. Lorenzoni and Lipparini (1999) confirmed a positive effect of debt over firm competitiveness. Similar result was confirmed by Lixin and Lin (2008). Campello (2006) confirmed decreased in competitive edge by firm after using debt.

\section{LIQUIDITY}

Brealey et al. (2006) highlighted the issue of liquidity by quoting that 'determining the value of liquidity was one of the ten unsolved questions of finance'. Firm ability to meet its short term financial needs effectively without selling its asset on deep discount showed the good liquidity position. US financial crisis indicated the importance of liquidity in firm. 
A question rose in the mind that why firm needed to hold liquid assets and how it liquidity helped to gain competitive edge. Hicks (1936) highlighted that it was due to uncertainty firm to hold liquid assets to meet any short term requirement which if not yet countered going to decrease overall profitability. This was precautionary motive for holding liquid assets. Jensen (1986) highlighted stewardship motive for holding liquid asset. As management wanted to maximize shareholders wealth for that different profitable investments were made. For successful completion firm needed to maintain better liquidity position otherwise liquidity crisis increased the solvency risk clearly evident in US crisis (Burja, 2011).

Foley et al. (2007) highlighted another motive for holding liquid asset. Firm without cash needed at time of tax payment had to liquidate its liquid assets to pay the tax. This was named as tax perspective of liquidity.

Different studies were performed to investigate the impact of liquidity position on firm profitability. Kim et al. (1998) investigated the effect of liquidity on firm competitiveness in US and found a positive relationship. US firms were facing liquidity risk by focusing less on liquid assets so optimal level of liquidity must be maintained by firms. If firms were in better liquidity position, it turned to be competitive edge over others. Liquidity risk reduced firm profitability and stop capital mobilization confirmed by Dedu (2003). Stewardship approach confirmed that management of firm increased the firm competitiveness by increasing liquidity (Muhammad and Haider (2011)). Similar results observed in Gill and Mathur (2011) after studying Canadian service firms and Korankye and Adarquah (2013) after studying Ghanaian market. Filbeck and Krueger (2005) conducted study between 970 firms in 26 different sectors. The result showed negative effect of liquidity on competitiveness. These results were confirmed by Juan García-Teruel and Martinez-Solano (2007).

\section{PRODUCTIVE ASSET}

Higher the number of productive assets acquired by the firm proved to be the source of competitiveness. These assets increased the productivity of firm which ultimately decreased per unit cost of production that was competitive edge over other to sell quality products at cheaper prices. Productive assets used to raise cheap secured loans. Liquid assets cannot be used as security for raising secured funds because of discounting risk (Liu and Hung, 2006).

In underdeveloped countries technical capabilities were not so up to the mark so higher proportion of productive assets caused high cost of depreciation, represented the inefficient use reduced competitiveness (Deloof, 2003). Liargovas and Skandalis (2010) studied 102 firms listed on Athens Stock Market from 1997 to 2004 confirmed that firms were inefficient in fixed asset utilization that's why it reduced competitiveness of firm. Romanian chemical firms also showed similar results confirmed by Burja (2011). Okwo et al. (2012) confirmed bureaucracy a prime reason for this inefficient usage of productive assets.

\section{FIRM SIZE}

Firm with large amount of assets had large firm size which gave competitive edge over small size firms because such firms had potential to increase productivity. Through high productivity, firm achieved economies of scale as well as economies of scope. With passage of time firm's developed different techniques for proper and efficient utilization of asset. Hymer and Pashigian (1962) conducted study to confirm the relationship between size of US firms and their performance. Manufacturing firms were selected for study which showed negative relationship between the desired variables.

Shepherd (1972) and Leibenstein (1976) also confirmed the similar relationship and explained the reason behind negative relationship, which was due to huge investment on plant asset with less skilled worker to handle and use those assets. Firm took interest in human resource training and 
development to turn negative relationship into positive in future. Majumdar (1997) confirmed a positive relationship after studying 1020 Indian firms. These firms developed standard operating procedure for efficient utilization of large asset base. It also enabled the firm to achieve economies of scale and economies of scope (Punnose, 2008).

\section{INVESTMENT}

Investment defined as firm risk diversification strategy to invest in stocks of other firms over the period of time which helped the firm to reduce the liquidity and solvency risk as well as welcomed an income stream (Lev and Thiagarajan, 1993). However Abarbanell and Bushee (1997) found negative relationship between investment and firm competitiveness. The reason was no proper sources were identified by firm for investment as a result of which cost of investment was more then return from investment.

Beneish et al. (2001) and Fairfield et al. (2003) confirmed the negative relationship between investment and competitiveness. Further explained the reason that management had internal as well as external conflicts that resulted in unproductive investment due to which firm lose its competitive edge. However Li (2004) provided more detailed reason for such negative relationship after studying large US firms for over 40 years. Weak regulations were the main loop hole because of which firm's management involved in tunneling activities as a result of which higher investment reduced competitiveness. Countries with improved regulations get the benefits of investment which gave firm competitive advantage over other firms. Investment in technology firms increased the competitiveness of health sector firms (Thouin et al., 2008). The result was confirmed by Rakotomavo (2012).

\section{EXPORTING}

Reason behind selecting exporting as one of the factor for firm competitiveness because Girma et al. (2004) confirmed that domestic firm got competitive edge by performing exporting over nonexporting firms. Exporting helped to improve production quality by meeting international quality standards as well as helped firm to avail economies of scale and economies of scope. Bausch and Krist (2007) confirmed a positive association between exporting and firm competitiveness after performing meta-analysis. Access to big markets increased sale which compelled the firm to increase productivity as a result of which economies of scale and scope were possible as explained by Girma et al. (2004).

Bernard et al. (2007) performed a comparative study between exporting and non-exporting US firms. The result supported the point of view explained by Girma et al. (2004). Mayer and Ottaviano (2007) confirmed a positive relationship in European firms. However Grazzi (2012) performed regression and non-parametric tests which didn't show any significant relationship. Temouri et al. (2013) also showed similar result in UK firms as explained by Grazzi (2012). High cost associated with exporting reduced the benefits that was the main reason behind negative relationship with competitiveness. There were many conditions on exporting in UK which turned down competitiveness of exporting firms.

\section{MARKET SHARE}

Firm considered successful if income statements showed high sales. These high sales not just a source of revenue for business but also indicator of market shares of firm. Higher sales mean large market share. Firm with large market share had to increase productivity by achieving economies of scale and economies of scope which reduced firm cost of production and increased profitability and give competitive edge, that made market share a factor of competitiveness (Gale, 1972).

Shepherd (1972) found positive relationship between market share and competitiveness of firm. Jacobson and Aaker (1985) confirmed the result of Shepherd (1972)and rationale given by Gale 
(1972) for such relationship. Ailawadi et al. (1999) conducted investigation through structural equation modeling on percentage profitability changes over the period of six years. Positive relationship was confirmed. Result showed that per unit cost of acquiring high market share decreased with increased productivity which was already explained by Gale (1972).

\section{METHODOLOGY}

Data was collected from State Bank of Pakistan financial statement analysis report of non-financial companies listed on Karachi Stock Exchange. Time period of study was from 2002 to 2012. Only those firms were considered for analysis which were not in default section during 2002 to 2012 and incorporated before that.

\section{INDEPENDENT FINANCIAL FACTORS}

1. Leverage: Ratio of total debt to total equity was used which indicated that how many times debt financing was done in comparison with equity financing.

2. Productive Asset: Ratio of total fixed asset to total asset was used which provided the percentage of productive asset in total asset composition.

3. Liquidity: Ratio of current asset to current liabilities was used which portrayed that how many times firm was capable of paying most current financial obligation.

4. Investment: Ratio of total investment to total asset was used which described the percentage of investment in total asset composition that helped firm to meet liquidity problems as well as provided income stream.

5. Firm Size: Logarithm of total asset revealed the information about size of business of firm. Larger the value means firm had large asset base which was the indication of large business operation done by the firm.

\section{INDEPENDENT NONFINANCIAL FACTOR}

1. Market Share: Logarithm of net total sales depicted the information about market captured by firm. Larger the value means firm had more market share in comparison with its competitors.

2. Exporting: Dummy variable was used for exporting. One for firm involved in exporting while zero for no exporting by firm.

\section{DEPENDENT VARIABLE}

Return on Asset: Ration of net profit before tax to total asset was used which provided the information about how efficiently firm used total asset and returns were generated from assets. Value of this ratio showed firm profitability as a proxy for competitiveness.

\section{DESCRIPTIVE ANALYSIS}

Below mentioned table indicated that 902 panel data observations used in this study. Results confirmed that 83 percent of the firms were involved in exporting however firms on average firms were twice financed by debt to get tax benefits. Firms on average were only one time capable of meeting liquidity requirements but required asset discounted selling in worse conditions because of no proper liquidity management. Debt was also used in twice as compared to equity. About $47 \%$ of 
total asset composition was productive assets in average textile firms. Investment made by textile firms in stocks for diversification of portfolio was just $8 \%$. During the study time period average textile firm was earning about $3.10 \%$ return on its asset utilization. However highest competitive benchmark set by firm had $28.76 \%$ return generation.

\begin{tabular}{lrrrrr}
\hline \hline \multicolumn{5}{c}{ Table 1 Descriptive Statistics } & \\
\hline \hline & N & Minimum & Maximum & Mean & Std. Deviation \\
\hline \hline Exporting & 902 & 0 & 1 & 0.838174 & 0.368674 \\
Leverage & 902 & -6.60531 & 9.797721 & 2.009346 & 1.76494 \\
Liquidity & 902 & 0.076874 & 8.43183 & 1.20989 & 0.809975 \\
Productive Asset & 902 & 0.058066 & 0.880536 & 0.476221 & 0.156717 \\
Investment & 902 & $6.33 \mathrm{E}-07$ & 0.541875 & 0.080925 & 0.111153 \\
Firm Size & 902 & 4.577492 & 7.767119 & 6.241114 & 0.531619 \\
Market Share & 902 & 3.30103 & 7.686325 & 6.257126 & 0.530295 \\
ROA & 902 & -1.87493 & 0.287695 & 0.031017 & 0.115579 \\
\hline
\end{tabular}

\section{CORRELATION}

Table 2 showed the correlation among the variables. ROA had positive relationship with exporting, liquidity, investment, firm size and market share while negative correlation with leverage and fixed asset. Correlation with exporting was positive because it provided firm an opportunity to increase its productivity, increase sales by achieving economies of scale and economies of scope.

Firm used twice debt in comparison with equity financing to avail tax benefit but cost of using debt was greater than benefit which decreased competitiveness of firm. Firm with better liquidity management increased firm competitiveness however large debt proportion financing increased liquidity problems because of high cost of debt payments. Large amount of fixed asset increased productive capacity of the firm but it also increased cost of holding those assets as well as maintenance cost.

Textile average firm had $47 \%$ productive asset while the asset management was not much efficient which increased the cost of holding and maintenance then its productivity benefits and raised liquidity problems by increasing cash demand as maintenance cost. Firm competitiveness increased by diversification through investment made by firm but large productive asset holding reduced investment opportunities because of capital rationing. Firms with large asset base proved to have more potential which increased firm competitiveness while negative association with productive asset highlighted that firm's asset handling was not effective. 
Table 2 Correlation Statistics

\begin{tabular}{|c|c|c|c|c|c|c|}
\hline Exporting & Leverage & Liquidity & $\begin{array}{l}\text { Fixed } \\
\text { Asset }\end{array}$ & Investment & $\begin{array}{r}\text { Firm } \\
\text { Size }\end{array}$ & $\begin{array}{c}\text { Market } \\
\text { Share }\end{array}$ \\
\hline
\end{tabular}

\begin{tabular}{|c|c|c|c|c|c|c|c|}
\hline Exporting & 1 & & & & & & \\
\hline Leverage & 0.2037 & 1 & & & & & \\
\hline $\begin{array}{l}\text { Liquidity } \\
\text { Productive }\end{array}$ & -0.0238 & -0.1206 & 1 & & & & \\
\hline Asset & -0.2189 & -0.1845 & -0.3696 & 1 & & & \\
\hline Investment & 0.0972 & -0.1576 & -0.005 & 0.4247 & 1 & & \\
\hline $\begin{array}{l}\text { Firm Size } \\
\text { Market }\end{array}$ & 0.3741 & 0.1917 & 0.1477 & $\begin{array}{r}0.3868 \\
-\end{array}$ & 0.1360 & 1 & \\
\hline Share & 0.4192 & 0.1538 & 0.1872 & 0.4444 & 0.1310 & 0.8923 & 1 \\
\hline ROA & 0.0799 & -0.1534 & 0.1220 & 0.1032 & 0.0270 & 0.0382 & 0.1914 \\
\hline
\end{tabular}

\section{HAUSMAN TEST}

Pooled regression analysis was not appropriate technique because heterogeneous features of firms were not catered. Due to panel data the available choices were fixed effect or random effect model. To select which model was appropriate for this study Hausman Test was performed. Result confirmed that fixed effect model was appropriate for study.

Null Hypothesis: Random Effect Model Alternative Hypothesis: Fixed Effect Model

Table 3: Hausman Test (Textile)

Test Summary

Cross-Section Random
Chi-Sq. Statistic

17.7479
Chi-q.df. Probability

7 0.0132

VARIANCE INFLATION FACTOR TEST

Result confirmed no problem of multi-collinerity in the explanatory variables.

Table 4: VIF (Textile)

\begin{tabular}{lll}
\hline \hline & & \\
\hline Exporting & Tolerance & VIF \\
Leverage & 0.794 & 1.259 \\
Liquidity & 0.895 & 1.117 \\
Productive Asset & 0.817 & 1.223 \\
Investment & 0.695 & 1.437 \\
Firm Size & 0.978 & 1.022 \\
Market Share & 0.695 & 1.437 \\
\hline
\end{tabular}




\section{FIXED EFFECT MODEL}

Result of fixed effect model was revealed in table 5. Research model explained given in methodology section was capable of explaining only the $32.6 \%$ of the phenomena while rest was not explained due to many untapped factors. However significant $\mathrm{F}$ statistics confirm that variables coefficients were not valued zero. This model acquired from Liargovas and Skandalis (2008) and new variables introduced which were considered important for competitive edge from previous studies. The endogeneity reported in this model was removed by using Least Square Dummy Variable regression in which firm specific intercept of 84 companies were also included. Results showed that leverage had significantly negative relationship which supported study of Campello (2006). Textile firms were twice financed by debt as compared to equity. It increased firm cost of debt while reducing benefits from debt which put negative impact on firm competitiveness.

In case of Pakistan this debt usage was large because of government supportive police to textile firms during study time period. Firm raised high debt figures which increased cost of debt while decreased benefits of debt. Productive assets also had negative significant relationship with competitiveness which supported results and rationale presented by Deloof (2003), Burja (2011) and Okwo et al. (2012). As descriptive analysis confirmed that on average $47 \%$ of total asset were productive fixed assets. However firm was not equipped with skills to handle and maintain assets as a result of which cost of handling and maintenance was increased which reduced firm competitiveness. In this way economies of scope and economies of scale were not achieved.

It also increased liquidity problems because of productive asset at start required high cash inflows and took time to generate cash outflows that put negative impact on firm liquidity management. Proper liquidity management led to increase firm competitiveness. Firm size had negative significant relationship with competitiveness which contradicted with results of Punnose (2008). This exceptional case was due to huge proportion of productive assets in total textile firm asset composition with ineffective capability to handle and manage those assets. As a result of which cost increased due to which firm tried to achieve economies of scale and economies of scope. For that utilization of these assets were made more than optimal level which further increased depreciation cost. This ultimately damaged firm competitiveness. Now firm needed to decrease firm size to the level that was efficiently managed.

Market share had significant positive relationship with firm competitiveness and consistent with literature. Firm with maximum market share needed to produce more through which cost efficiencies were achieved and gave firm competitive edge over others competitors. Exporting also increased firm competitiveness however relationship was not significant because almost $87 \%$ of the firms performed it. In order to get competitive edge firm needed to identify some new nonfinancial activities that were not performed by others. Investment reduced competitiveness of firm due to no proper regulation on management while management involved in tunneling activities. However relationship was insignificant because only $8 \%$ of the firms performed investment for diversification purpose. 
Table 5: Textile Sector Fixed Effect Model

\begin{tabular}{lllll}
\hline \hline Variable & Coefficient & $\begin{array}{l}\text { Standard } \\
\text { Error }\end{array}$ & T-Statistics & Probabilities \\
\hline \hline Constant & -0.08895 & 0.199217 & -0.44649 & 0.6554 \\
Exporting & 0.017644 & 0.014034 & 1.257224 & 0.2090 \\
Leverage & -0.00788 & 0.002633 & -2.99326 & 0.0028 \\
Liquidity & 0.003937 & 0.007859 & 0.50089 & 0.6166 \\
Productive Asset & -0.10005 & 0.044436 & -2.25143 & 0.0246 \\
Investment & -0.06499 & 0.070566 & -0.92101 & 0.3573 \\
Firm Size & -0.15758 & 0.031464 & -5.0083 & 0.0000 \\
Market Share & 0.184705 & 0.02125 & 8.691976 & 0.0000 \\
R-squared & & & & 0.326176 \\
Adj R-squared & & & & 0.24394 \\
F-statistic & & & & 0.0000 \\
Prob(F-statistic) & & & & \\
\hline \hline
\end{tabular}

\section{CONCLUSION \& RECOMMENDATION}

In this study a new direction to study firm competitiveness was introduced by combining financial and not financial factors. Competitiveness defined as long run profitability of proxy by ROA (Return on Asset). Analysis confirmed that textile firms were highly leveraged firms which increased cost of leverage and decreased firm competitiveness. Productive asset management was not up to the mark and these assets were on average $47 \%$ of total asset composition.As already showed that firm asset management was not effective so further enhancement in asset base specially in productive assets was not preferred otherwise competitiveness decreased. Firm needed to attain maximum market share possible because it required producing more through which cost efficiencies were achieved and gave firm competitive edge over others competitors.

However exporting also increased firm competitiveness but almost $87 \%$ of the firms performed it. In order to get competitive edge firm needed to identify some new nonfinancial activities that were not performed by others. Investment reduced competitiveness of firm due to no proper regulation on management. As management involved in tunneling activities.

\section{Reference}

[1] ABARBANELL, J. S. \& BUSHEE, B. J. 1997. Fundamental analysis, future earnings, and stock prices. Journal of Accounting Research, 1-24.

[2] AILAWADI, K., FARRIS, P. \& SHAMES, E. 1999. Trade promotion: Essential to selling through resellers. MIT Sloan Management Review, 41, 83.

[3] BAUSCH, A. \& KRIST, M. 2007. The effect of context-related moderators on the internationalization-performance relationship: Evidence from meta-analysis. Management International Review, 47, 319-347.

[4] BENEISH, M. D., LEE, C. M. \& TARPLEY, R. L. 2001. Contextual fundamental analysis through the prediction of extreme returns. Review of Accounting Studies, 6, 165-189.

[5] BERNARD, A. B., JENSEN, J. B., REDDING, S. J. \& SCHOTT, P. K. 2007. Firms in international trade. National Bureau of Economic Research.

[6] BREALEY, R. A., MYERS, S. C. \& ALLEN, F. 2006. Corporate finance, 8. Auflage, New York.

[7] BURJA, C. 2011. Factors influencing the companies' profitability. Annales Universitatis Apulensis, Series Oeconomica, 13, 215-224. 
[8] CAMPELLO, M. 2006. Debt financing: Does it boost or hurt firm performance in product markets? Journal of Financial Economics, 82, 135-172.

[9] DEDU, V. 2003. Administration and Banking Auditing. Economic Publishing, Bucharest.

[10] DELOOF, M. 2003. Does working capital management affect profitability of Belgian firms? Journal of business finance \& Accounting, 30, 573-588.

[11] FAIRFIELD, P. M., WHISENANT, J. S. \& YOHN, T. L. 2003. Accrued earnings and growth: Implications for future profitability and market mispricing. The accounting review, 78, 353-371.

[12] FILBECK, G. \& KRUEGER, T. M. 2005. An analysis of working capital management results across industries. American Journal of Business, 20, 11-20.

[13] FOLEY, C. F., HARTZELL, J. C., TITMAN, S. \& TWITE, G. 2007. Why do firms hold so much cash? A tax-based explanation. Journal of Financial Economics, 86, 579-607.

[14] GALE, B. T. 1972. Market share and rate of return. The Review of Economics and Statistics, 412-423.

[15] GILL, A. \& MATHUR, N. 2011. The impact of board size, CEO duality, and corporate liquidity on the profitability of Canadian service firms. Journal of Applied Finance and Banking, 1, 83-95.

[16] GIRMA, S., GREENAWAY, D. \& KNELLER, R. 2004. Does exporting increase productivity? A microeconometric analysis of matched firms. Review of International Economics, 12, 855-866.

[17] GRAZZI, M. 2012. Export and firm performance: Evidence on productivity and profitability of Italian companies. Journal of Industry, Competition and Trade, 12, 413-444.

[18] HICKS, J. R. 1936. Keynes' theory of employment. The Economic Journal, 238-253.

[19] HYMER, S. \& PASHIGIAN, P. 1962. Firm size and rate of growth. The Journal of Political Economy, 556-569.

[20] JACOBSON, R. \& AAKER, D. A. 1985. Is market share all that it's cracked up to be? The Journal of Marketing, 11-22.

[21] JENSEN, M. C. 1986. Agency cost of free cash flow, corporate finance, and takeovers. Corporate Finance, and Takeovers. American Economic Review, 76.

[22] JENSEN, M. C. \& MECKLING, W. H. 1976. Theory of the firm: Managerial behavior, agency costs and ownership structure. Journal of financial economics, 3, 305-360.

[23] JUAN GARCÍA-TERUEL, P. \& MARTINEZ-SOLANO, P. 2007. Effects of working capital management on SME profitability. International Journal of managerial finance, 3, 164-177.

[24] KIM, C.-S., MAUER, D. C. \& SHERMAN, A. E. 1998. The determinants of corporate liquidity: Theory and evidence. Journal of financial and quantitative analysis, 33, 335-359.

[25] KORANKYE, T. \& ADARQUAH, R. S. 2013. Empirical Analysis of Working Capital Management and its Impact on the Profitability of Listed Manufacturing Firms in Ghana. Research Journal of Finance and Accounting, 4, 124-131.

[26] LALL, S. 2001. Competitiveness, Technology and Skills, ERIC.

[27] LEIBENSTEIN, H. 1976. Beyond economic man, Harvard university press.

[28] LEV, B. \& THIAGARAJAN, S. R. 1993. Fundamental information analysis. Journal of Accounting research, 190-215.

[29] LI, D. 2004. The implications of capital investment for future profitability and stock returns: an over-investment perspective. University of California, Berkeley.

[30] LIARGOVAS, P. \& SKANDALIS, K. 2008. Factors Affecting Firms' Financial Performance: The Case of Greece. 
[31] LIARGOVAS, P. \& SKANDALIS, K. 2010. Factors Affecting Firm Competitiveness: The Case of Greek Industry. European institute Journal, 2, 184-197.

[32] LIU, Y.-C. \& HUNG, J.-H. 2006. Services and the long-term profitability in Taiwan's banks. Global Finance Journal, 17, 177-191.

[33] LIXIN, X. \& LIN, C. The Relationship Between Debt Financing and Market Value of Company: Empirical Study of Listed Real Estate Company of China. Proceedings of the 7th International Conference on Innovation \& Management, 2008.

[34] LORENZONI, G. \& LIPPARINI, A. 1999. The leveraging of interfirm relationships as a distinctive organizational capability: a longitudinal study. Strategic Management Journal, 20, 317-338.

[35] MAJUMDAR, S. K. 1997. The impact of size and age on firm-level performance: some evidence from India. Review of industrial organization, 12, 231-241.

[36] MAYER, T. \& OTTAVIANO, G. I. 2007. The happy few: the internationalisation of European firms, Bruegel Brussels.

[37] MILLER, M. H. 1977. DEBT AND TAXES*. the Journal of Finance, 32, 261-275.

[38] MODIGLIANI, F. \& MILLER, M. H. 1958. The cost of capital, corporation finance and the theory of investment. The American economic review, 261-297.

[39] MOMAYA, K. \& SELBY, K. 1998. International competitiveness of the Canadian construction industry: a comparison with Japan and the United States. Canadian journal of civil engineering, 25, 640-652.

[40] MUHAMMAD, A. \& HAIDER, S. I. 2011. INTERDISCIPLINARY JOURNAL OF CONTEMPORARY RESEARCH IN BUSINESS. IJCRB, 481.

[41] MURTHS, T. \& LENWAY, S. 1998. Country capabilities and the strategic state: How national political institutions affect MNC strategies. Strategic Management Journal, 15, 113 119.

[42] MYERS, S. C. \& MAJLUF, N. S. 1984. Corporate financing and investment decisions when firms have information that investors do not have. Journal of financial economics, 13, 187221.

[43] OKWO, I. M., OKELUE, U. D. \& NWEZE, A. U. 2012. Investment in fixed assets and firm profitability: Evidence from the Nigerian brewery industry. European Journal of Business and Management, 4, 10-17.

[44] PUNNOSE, E. M. 2008. A profitability analysis of Business group firms vs. Individual firms in the Indian Electrical Machine manufacturing industry. The Icfai Journal of Management Research, 7, 52-76.

[45] RAKOTOMAVO, M. T. 2012. Corporate investment in social responsibility versus dividends? Social Responsibility Journal, 8, 199-207.

[46] SHEPHERD, W. G. 1972. The elements of market structure. The review of economics and statistics, 25-37.

[47] TEMOURI, Y., VOGEL, A. \& WAGNER, J. 2013. Self-selection into export markets by business services firms-Evidence from France, Germany and the United Kingdom. Structural Change and Economic Dynamics, 25, 146-158.

[48] THOUIN, M. F., HOFFMAN, J. J. \& FORD, E. W. 2008. The effect of information technology investment on firm-level performance in the health care industry. Health Care Management Review, 33, 60-68. 